\title{
Clinical efficacy and safety of autologous stem cell transplantation for patients with ST-segment elevation myocardial infarction
}

This article was published in the following Dove Press journal:

Therapeutics and Clinical Risk Management

I August 2016

Number of times this article has been viewed

\section{Rong $\mathrm{Li}^{1, *}$ \\ Xiao-Ming $\mathrm{Li}^{2, *}$ \\ Jun-Rong $\mathrm{Chen}^{3}$}

'Department of Intensive Care Unit, The People's Hospital of Baoji City, ${ }^{2}$ Department of Cardiovascular Medicine, ${ }^{3}$ Department of Function, Baoji Central Hospital, Baoji, Shaanxi, People's Republic of China

*These authors contributed equally to this work
Correspondence: Rong $\mathrm{Li}$

Department of Intensive Care Unit, The People's Hospital of Baoji City, No 24 Xinhua Lane, Jinger Road, Baoji City, Shaanxi Province 721000 People's Republic of China Tel/fax +86 9l 73272307 Email dr_lirong@163.com
Purpose: The purpose of this study is to evaluate the therapeutic efficacy and safety of stem cells for the treatment of patients with ST-segment elevation myocardial infarction (STEMI).

Materials and methods: We performed a systematic review and meta-analysis of relevant published clinical studies. A computerized search was conducted for randomized controlled trials of stem cell therapy for STEMI.

Results: Twenty-eight randomized controlled trials with a total of 1,938 STEMI patients were included in the present meta-analysis. Stem cell therapy resulted in an improvement in long-term (12 months) left ventricular ejection fraction of 3.15\% (95\% confidence interval 1.01-5.29, $P<0.01$ ). The 3-month to 4-month, 6-month, and 12-month left ventricular endsystolic volume showed favorable results in the stem cell therapy group compared with the control group $(P \leq 0.05)$. Significant decrease was also observed in left ventricular end-diastolic volume after 3-month to 4-month and 12-month follow-up compared with controls $(P<0.05)$. Wall mean score index was reduced significantly in stem cell therapy group when compared with the control group at 6-month and 12-month follow-up $(P=0.01)$. Moreover, our analysis showed a significant change of 12-month infarct size decrease in STEMI patients treated with stem cells compared with controls $(P<0.01)$. In addition, no significant difference was found between treatment group and control in adverse reactions $(P>0.05)$.

Conclusion: Overall, stem cell therapy is efficacious in the treatment of patients with STEMI, with low rates of adverse events compared with control group patients.

Keywords: ST-segment elevation myocardial infarction, bone marrow mononuclear cells, hematopoietic stem cells, endothelial progenitor cells, mesenchymal stem cells, meta-analysis

\section{Introduction}

Acute myocardial infarction (AMI) remains the leading cause of disability and mortality throughout the world, despite substantial advances in therapeutic approaches, including pharmacotherapy, percutaneous coronary intervention, device-based therapies, and cardiac transplantation. ${ }^{1-4}$ Usually, heart failure is largely caused by ischemic heart disease. ${ }^{5}$ AMI leads to regional ischemia and subsequent myocardial tissue necrosis. AMI is generally caused by the formation of a blockage in the coronary arteries supplying blood to the heart, which is primarily due to the unstable buildup of cholesterol, leukocytes, and fat. ${ }^{6,7}$ AMI is further divided into two subclasses, ST-segment elevation myocardial infarction (STEMI) and non-ST-segment elevation myocardial infarction (NSTEMI). STEMI accounted for roughly $25 \%-40 \%$ of AMI and is known as a combination of symptoms including a typical ischemic chest pain that persists for $>20$ minutes and elevated serum myocardial necrosis marker 
concentrations, as well as a typical class of ST-segment elevation on the electrocardiogram. ${ }^{8-10}$ Currently, more effective treatments are strongly required to be explored, due to the high mortality and disability rate in STEMI patients. Application of stem cell therapy has opened a new chapter for ischemic heart disease treatment. Various methods of stem cells have been used to treat STEMI patients in recent years, including clinical setting, cell type, the route, and timing of cell delivery. ${ }^{11-14}$ Stem cell therapy is confirmed to be safe, although the efficacy remains controversial.

Stem cells used in clinical trials can be roughly divided into four categories: bone marrow mononuclear cells (BM-MNCs), hematopoietic stem cells (HSCs), endothelial progenitor cells (EPCs), and mesenchymal stem cells (MSCs). ${ }^{11-15}$ ClinicalTrials.gov lists 25 registered trials on STEMI with the keywords of "stem cells" and "STEMI" until January 4, 2016: one in Phase I, 15 in Phase II, eight in Phase III, and one in Phase IV (https://www.ClinicalTrials.gov) $){ }^{16} 14$ trials among them have been completed. Recently, the most trending type of stem cells used for STEMI are bone marrowderived cells (BMCs). ${ }^{11-15}$ BMCs contain multiple cluster of stem cells, including HSCs, EPCs, and MSCs. In July 2011, Hearticellgram-AMI (FCB-Pharmicell, Seongnam, South Korea) was approved by the Korean Food and Drug Administration for the treatment of AMI, and MSCs were the main ingredient of this drug.

In this study, we performed a systematic review and metaanalysis of randomized controlled trials (RCTs) to assess the efficacy and safety of stem cell therapy in the treatment of patients with STEMI. The aim was to evaluate the clinical response to stem cell therapy by assessing left ventricular ejection fraction (LVEF), left ventricular end-systolic volume (LVESV) and left ventricular end-systolic volume index (LVESVI), left ventricular end-diastolic volume (LVEDV) and left ventricular end-diastolic volume index (LVEDVI), wall mean score index (WMSI), infarct size (IS), and adverse events (AEs).

\section{Materials and methods}

\section{Search strategy, study design, and eligibility criteria}

Randomized controlled clinical trials were identified by searching PubMed, EMBASE, the Cochrane Center Register of Controlled Trials, the Central medical literature, the Wangfang Database and China Journal Net, and the China Science and Technology Periodical Database from 1966 to February 2016. The search strategy included the keywords ("bone marrow mononuclear cells" OR "mesenchymal stem cells" OR "haemopoietic stem cells" OR "endothelial progenitor cells" OR "stem cells") AND ("ST-segment elevation myocardial infarction" OR "STEMI") AND "randomized controlled trial" without language limitation. The registered trials with publication citations were displayed at the bottom of the "full-text view" tab of a study record, under the "more information" heading. All retrieved articles were checked by the relevant review papers, previously published trials, and postgraduate articles. We also searched ClinicalTrials.gov website for the information of ongoing trials. The studies on animals and cell lines, case reports, investigating multiple types of AMI, no details of patients, and not RCTs were excluded.

\section{Data selection criteria and quality assessment}

Study selection and data extraction were performed independently by two reviewers (Rong Li and Xiao-Ming Li) using a standardized approach and according to the quality of reporting of meta-analyses (QUOROM) recommendations. Studies were eligible for inclusion if 1) they published, prospective, RCTs in human BM-MNCs or MSCs or HSCs or EPC transplantation therapy for STEMI patients, 2) the data of LVEF were reported both prior to therapy and at the end of the study, 3) they enrolled six or more patients in each group, and 4) the dose of BM-MNCs is between $10^{7}$ and $10^{8}$; the dose of MSCs, HSCs, and EPCs should be $>10^{6}$. The exclusion criteria were 1) studies with inadequate key background data of patients and 2) ongoing or unpublished studies and duplicate reports. Study features extracted included the first author's name, country and year of publication, the phase of clinical trial, trial identifier, number of patients, sample size per arm, mean patient age, time from STEMI to cell delivery, the kinds of stem cells, cell dose and route of administration, and myocardial function measurement. Any data that could not be directly obtained from the articles were calculated from the graphed data using Adobe Illustrator and Photoshop.

\section{Definition of outcome measures}

LVEF improvement was defined as the mean change in the LVEF from baseline. LVESV, LVESVI, LVEDV, and LVEDVI reduction were defined as the mean changes in the LVESV, LVESVI, LVEDV, and LVEDVI from baseline, respectively. WMSI and IS reduction were defined as the mean changes in the WMSI and IS from baseline, respectively. The primary end points were absolute change in global LVEF, LVESV, and LVESVI from baseline. Secondary end 
points included changes in LVEDV, LVEDVI, WMSI, IS, and AEs. Short-term (3-4 months and 6 months) and long-term (12 months) data were separately analyzed for each group.

\section{Statistical analysis}

In this meta-analysis, we compared the stem cell treatment groups from the trials with their respective control groups using Review Manager (Version 5.0, Nordic Cochrane Centre, Copenhagen, Denmark). The stem cell treatment effects were reflected by the weighted mean differences (WMDs) and odds ratios with $95 \%$ confidence intervals (CIs). Fixed- and randomeffect models were used to estimate stem cell treatment effects. Heterogeneity among the trials was assessed with the $\chi^{2}$-based $Q$-test and the $I^{2}$ statistic, and $I^{2}>50 \%$ was considered to indicate a high level of heterogeneity. A random-effect model was used when statistical heterogeneity was confirmed; otherwise, a fixed-effect model was used. $P \leq 0.05$ was considered to be statistically significant in all analysis, and all reported $P$-values resulted from two-sided version tests of the respective tests. To assess the possibility of publication bias, Egger's test and Begg's test were used (Stata Version 12.0; Stata Corporation, College Station, TX, USA).

\section{Results Trial selection}

The data search yielded 101 references, 51 of which were excluded for various reasons ( 21 review articles, seven full texts were not available, four animal models or in vitro experiments, six case reports, and 13 due to multiple publication). An additional 50 studies were excluded because they were published in other languages, did not provide detailedenough clinical data, or were not RCTs. Finally, 28 trials met the specified inclusion criteria. ${ }^{17-44}$ Figure 1 provides a flowchart illustrating the search results and mechanisms of exclusion for certain studies. The funnel plots for the analyses regarding AEs were largely symmetrical (Figure S1). Both Begg's test and Egger's test showed no clear evidence of publication bias $(P>0.05)$. Thus, publication bias did not seem to be present in our study.

\section{Baseline patient characteristics}

The baseline characteristics of the patients in the 28 selected publications are listed in Table 1. The trials involved a total of 1,938 patients with STEMI. All of the 28 papers were fully published over the period from 2006 to 2015 . Sample size ranged from a minimum of 12 to a maximum

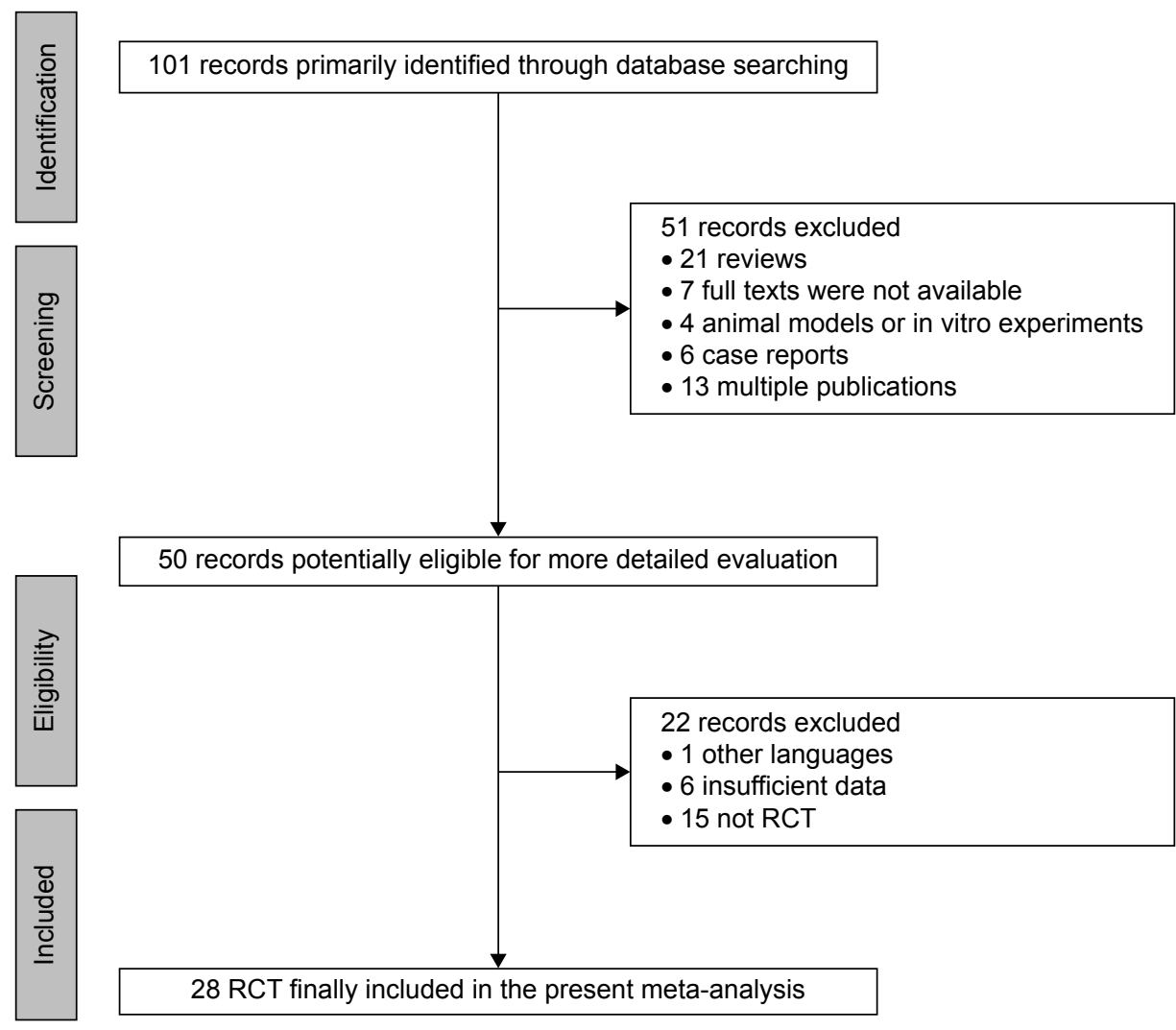

Figure I Flow diagram showing the study identification, screening, and inclusion process. Abbreviation: RCT, randomized controlled trial. 


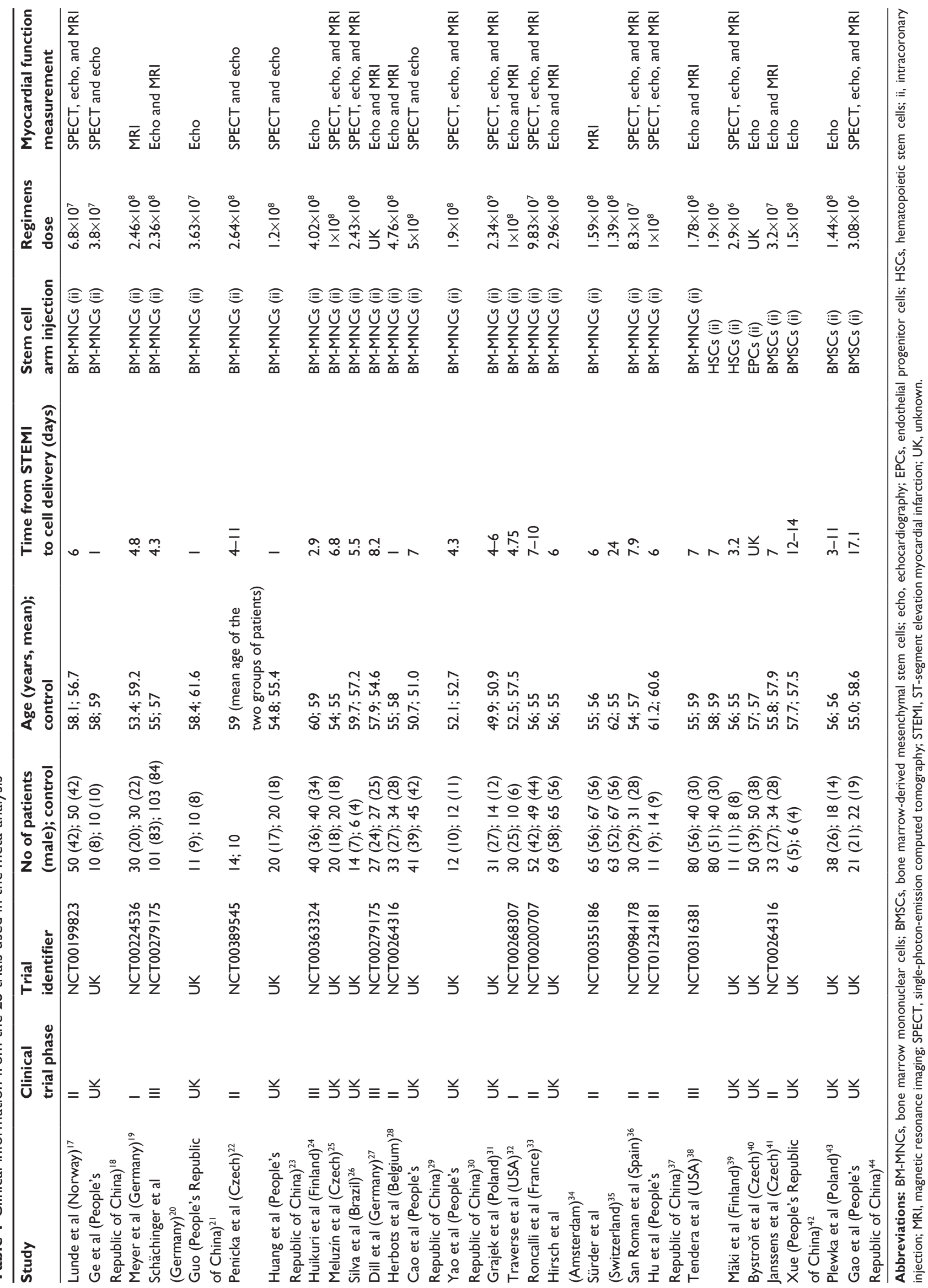


of 204 patients. The percentage of male study participants ranged from $55 \%$ to $93 \%$. Time from STEMI to cell delivery ranged from 1 day to 24 days. The average ages of enrolled patients were between 50.7 years and 62 years. In all of the trials, stem cell therapy was evaluated in STEMI patients with BM-MNCs in 22 studies, ${ }^{17-38}$ HSCs in two studies, ${ }^{38,39}$ EPCs in one study, ${ }^{40}$ and bone marrow mesenchymal stem cells (BMSCs) in four studies. ${ }^{41-44}$ The number of stem cells injected ranged from $2.9 \times 10^{6}$ to $5 \times 10^{8}$. The routes of stem cells injection used were all intracoronary injection, which is the most promising way of transplantation.

\section{Left ventricular ejection fraction}

\section{Three to 4 months LVEF}

Information on the 3-month to 4-month LVEF improvementbased SPECT was available from seven trials. . $2,25,26,28,31,33,34^{-1}$ These seven trials contained a total of 423 patients, of whom 230 patients received stem cell treatment, and 193 control patients did not receive stem cell therapy. The WMD of changes in LVEF (\%) of patients receiving stem cell treatment was a no-significant increase of $-0.11 \%(95 \%$ CI $-2.03-1.82, P>0.05, I^{2}=70 \%$ ) compared with that of the controls (Figure 2A). In five studies that reported 3-month to 4-month LVEF-based echocardiography (echo), the WMD of changes in LVEF was $2.76 \%$ (95\% CI 0.90-4.62, $P<0.01$ ). And the corresponding $I^{2}$ was $67 \%$ (Figure 2B). In two studies ${ }^{20,35}$ that reported 3-month to 4-month LVEFbased magnetic resonance imaging (MRI), the WMD of changes in LVEF was $2.02 \%$ (95\% CI $0.71-3.32, P=0.002$, $I^{2}=0 \%$; Figure $2 \mathrm{C}$ ).

\section{Six-month LVEF}

Information on the 6-month LVEF improvement-based SPECT was available from seven trials, ${ }^{17,25,26,30,31,37,39}$ including a total of 273 patients (149 of whom received stem cell treatment; Figure 2). The WMD of changes in LVEF (\%) of patients receiving stem cell treatment was a no-significant increase of $2.91 \%\left(95 \% \mathrm{CI}-0.15-5.96, P>0.05, I^{2}=80 \%\right)$ compared with that of the control group. In nine studies that reported 6-month LVEF-based echo, the WMD of changes

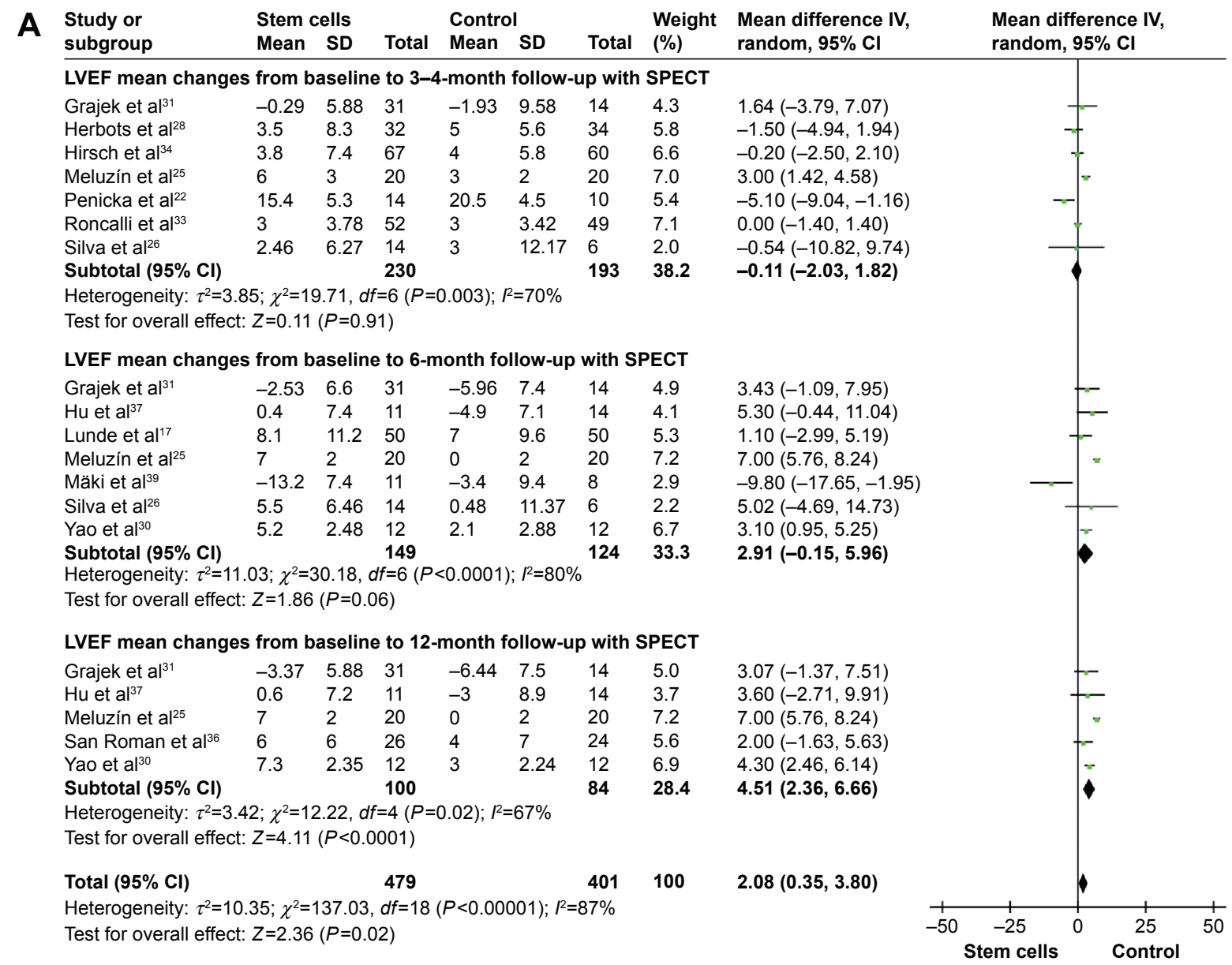

Figure 2 (Continued) 


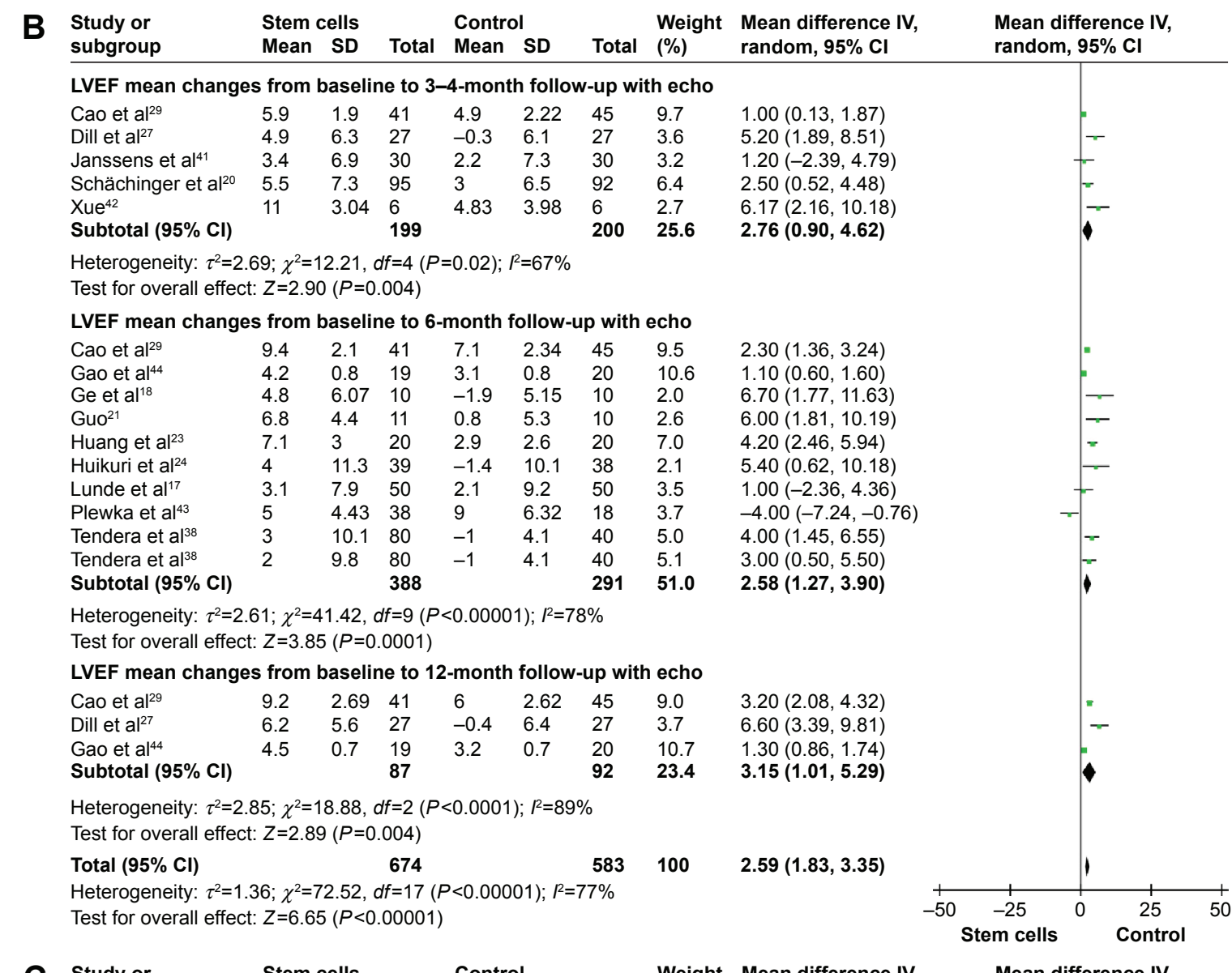

\begin{tabular}{|c|c|c|c|c|c|c|c|c|}
\hline $\begin{array}{l}\text { Study or } \\
\text { subgroup }\end{array}$ & $\begin{array}{l}\text { Stem } \\
\text { Mean }\end{array}$ & $\begin{array}{l}\text { ells } \\
\text { SD }\end{array}$ & Total & $\begin{array}{l}\text { Contro } \\
\text { Mean }\end{array}$ & SD & Total & $\begin{array}{l}\text { Weight } \\
(\%)\end{array}$ & $\begin{array}{l}\text { Mean difference } \\
\text { random, } 95 \% \mathrm{Cl}\end{array}$ \\
\hline \multicolumn{9}{|c|}{ LVEF mean changes from baseline to 3-4-month follow-up with MRI } \\
\hline Schächinger et al ${ }^{20}$ & 5.5 & 7.3 & 95 & 3 & 6.5 & 92 & 21.3 & $2.50(0.52,4.48)$ \\
\hline & 1.4 & 6.4 & 58 & -0.4 & 7.21 & 60 & 19 & $.66,4.26)$ \\
\hline Sürder et al $\left.\right|^{35}$ & 1.1 & 5.84 & 49 & -0.4 & 7.21 & 60 & 19.6 & $1.50(-0.95,3.95)$ \\
\hline Subtotal $(95 \% \mathrm{Cl})$ & & & 202 & & & 212 & 60.4 & $2.02(0.71,3.32)$ \\
\hline
\end{tabular}

Heterogeneity: $\tau^{2}=0.00 ; \chi^{2}=0.43, d f=2(P=0.81) ; R^{2}=0 \%$

Test for overall effect: $Z=3.03(P=0.002)$

LVEF mean changes from baseline to 6-month follow-up with MRI

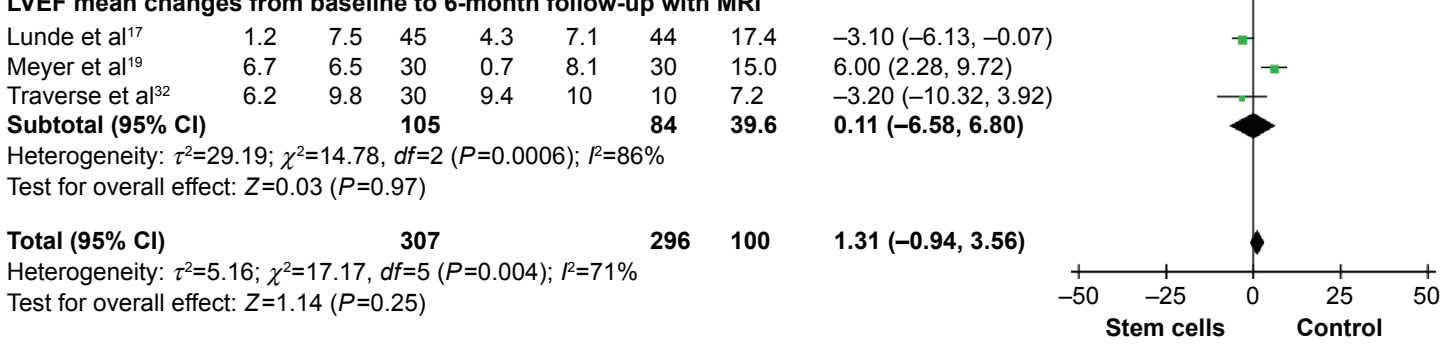

Figure 2 Forest plots of weighted mean difference, with $95 \% \mathrm{Cl}$ in LVEF in patients undergoing stem cell therapy and controls.

Notes: (A) LVEF-based SPECT, (B) LVEF-based echo, and (C) LVEF-based MRI. Random-effect models (Mantel-Haenszel method) were used. Each trial is represented by a square, and the size of the square is proportional to the information in that trial. The ends of the horizontal bars denote $95 \%$ Cls. Black diamond gives the overall results of all trials.

Abbreviations: $\mathrm{Cl}$, confidence interval; echo, echocardiography; IV, inverse variance; LVEF, left ventricular ejection fraction; MRI, magnetic resonance imaging; SPECT, single-photon-emission computed tomography.

in LVEF was $2.58 \%\left(95 \%\right.$ CI $\left.1.27-3.90, P<0.01, I^{2}=78 \%\right)$. Three studies ${ }^{17,19,32}$ measured LVEF with MRI at 6 months. Pooled analysis of these data did not show a significant improvement in STEMI patients receiving stem cell therapy (WMD 0.11, 95\% CI -6.58-6.80, $P>0.05, P^{2}=86 \%$ ).

\section{Twelve-month LVEF}

Information on the 12-month LVEF improvement-based SPECT was available from five trials, ${ }^{25,30,31,36,37}$ which contained a total of 184 patients (100 of whom received stem cell treatment; Figure 2). Stem cell therapy led to 12-month 
LVEF of $4.51 \%$ improvement $(95 \%$ CI 2.36-6.66, $P<0.01$, $I^{2}=67 \%$ ) in STEMI patients. Three studies ${ }^{27,29,44}$ measured LVEF with echo at 12 months. Pooled analysis of these data showed a significant improvement in STEMI patients receiving stem cell therapy (WMD 3.15, 95\% CI 1.01-5.29, $P<0.01, I^{2}=89 \%$; Figure 2).

\section{Left ventricular end-systolic volume and left ventricular end-systolic volume index}

WMD of changes in LVESV and LVESVI at 3-4 months was $-6.42 \mathrm{~mL}\left(95 \% \mathrm{CI}-11.34\right.$ to $\left.-1.49, P=0.01, I^{2}=80 \%\right)$ and $-1.70 \mathrm{~mL}\left(95 \% \mathrm{CI}-5.18-1.78, P>0.05, I^{2}=0 \%\right)$. In nine trials that reported 6-month outcomes, the WMD of changes in LVESV was $-3.78 \mathrm{~mL}(95 \% \mathrm{CI}-7.50$ to -0.07 , $\left.P=0.05, I^{2}=92 \%\right)^{24,25,29-32,37,38,44}$ In two studies that reported 6-month outcomes, the WMD of changes in LVESVI was $-2.56 \mathrm{~mL}\left(95 \% \mathrm{CI}-8.58-3.46, P>0.05, I^{2}=0 \%\right) .{ }^{19,39}$ Information on the 12-month LVESV was available form eight trials..$^{25,27,29-31,36,37,44}$ These eight trials contained a total of 363 patients (187 of whom received stem cell treatment and 176 controls who did not receive). The WMD of changes in LVESV was $-8.50 \mathrm{~mL}(95 \% \mathrm{CI}-13.30$ to $-3.70, P<0.01$, $I^{2}=91 \%$; Figure 3 ).

\section{Left ventricular end-diastolic volume and left ventricular end-diastolic volume index}

WMD of changes in LVEDV and LVEDVI at 3-4 months was $-6.61 \mathrm{~mL}\left(95 \% \mathrm{CI}-12.54\right.$ to $\left.-0.69, P=0.03, I^{2}=76 \%\right)$ and $-2.03 \mathrm{~mL}\left(95 \% \mathrm{CI}-6.03-1.96, P>0.05, I^{2}=0 \%\right)$.

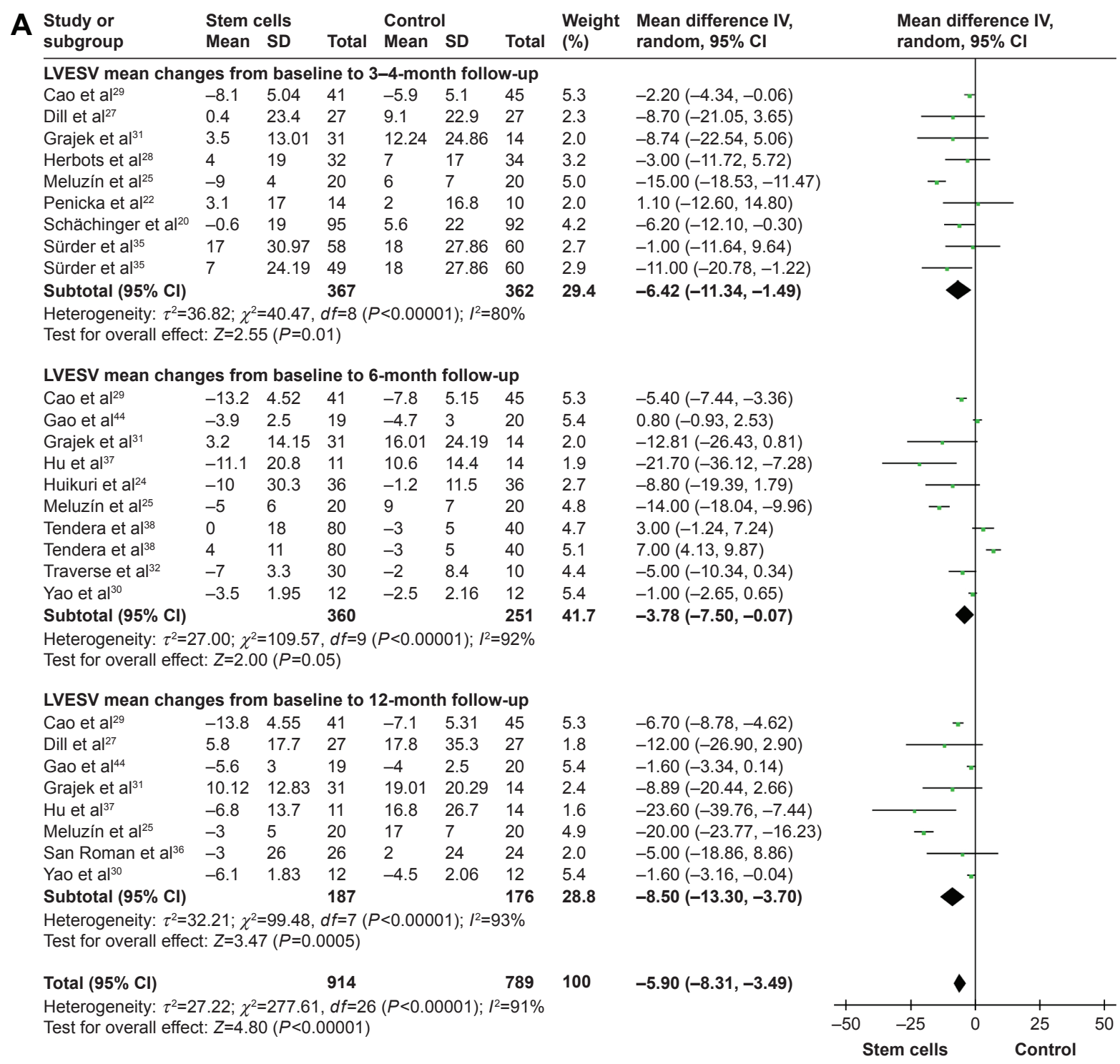

Figure 3 (Continued) 


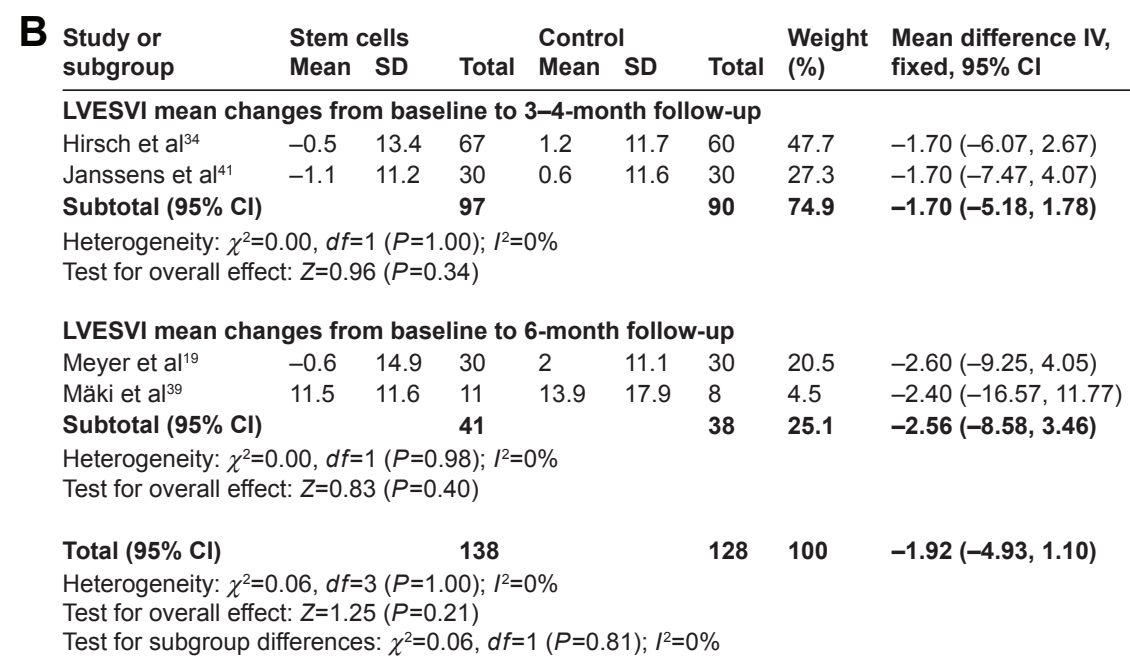

Figure 3 Forest plots of WMD with $95 \% \mathrm{Cl}$ in patients undergoing stem cell therapy and controls in LVESV (A) and LVESVI (B).

Note: Random- and fixed-effect models were used.

Abbreviations: WMD, weighted mean difference; Cl, confidence interval; IV, inverse variance; LVESV, left ventricular end-systolic volume; LVESVI, left ventricular endsystolic volume Index.

In ten trials that reported 6-month outcomes, the WMD of changes in LVEDV was $-2.75 \mathrm{~mL}$ (95\% CI -6.58-1.08, $\left.P>0.05, I^{2}=86 \%\right) .{ }^{17,24,25,29-32,37,38,44}$ In two studies that reported 6-month outcomes, the WMD of changes in LVEDVI was $2.71 \mathrm{~mL}\left(95 \% \mathrm{CI}-5.18-10.59, P>0.05, I^{2}=43 \%\right) .{ }^{19,39}$ Information on the 12-month LVEDV was available form nine trials. ${ }^{17,25,27,29-31,36,37,44}$ These trials included a total of 452 patients ( 232 of whom received stem cell treatment and 220 controls who did not receive). The WMD of changes in LVEDV was $-5.39 \mathrm{~mL}(95 \% \mathrm{CI}-9.71$ to $-1.06, P=0.01$, $I^{2}=79 \%$; Figure 4 ).

\section{Wall mean score index}

Pooled analysis of three trials with measurement of 3-month to 4-month WMSI did not show statistic significance with stem cell treatment patients compared with the controls, and the WMD of WMSI changes was -0.02 (95\% CI -0.14-0.10, $P>0.05, I^{2}=71 \%$ ). Pooled analysis was also performed on six trials at 6 months. ${ }^{29,31,37,39,43,44}$ The WMD of WMSI changes was statistically significant, which was -0.03 (95\% CI -0.05 to $-0.01, P=0.01, I^{2}=12 \%$ ). Information on the 12 -month WMSI improvement was available from five studies, ${ }^{29,31,36,37,44}$ which included a total of 245 patients (128 of whom received stem cell treatment; Figure 5). And the WMD of WMSI changes was statistically significant, which was $-0.04(95 \%$ CI -0.06 to $-0.01, P=0.01, I^{2}=24 \%$ ).

\section{Infarct size}

Pooled analysis of three trials with measurement of 3-month to 4-month IS did not show statistical significance with stem cell treatment patients compared with controls, and the WMD of IS changes was $-0.03\left(95 \% \mathrm{CI}-0.24-0.19, P>0.05, I^{2}=0 \%\right)$. Pooled analysis was performed on four trials at 6 months. The WMD of IS changes was not statistically significant, which was -0.56 (95\% CI $\left.-2.88-1.77, P>0.05, I^{2}=72 \%\right)$. Information on the 12-month IS improvement was available from three trials, ${ }^{29,30,36}$ which included a total of 160 patients (79 of whom received stem cell treatment). And the WMD of IS changes was statistically significant, which was -2.22 (95\% CI -3.28 to $-1.15, P<0.01, I^{2}=0 \%$; Figure 6 ).

\section{Toxicity and adverse reactions}

The AEs of patients were summarized in Table 2, including death, ${ }^{20,32-38}$ cardiac death, ${ }^{33,40}$ reinfarction, ${ }^{20,32-36,38,40}$ rehospitalization for heart failure (HF), ${ }^{20,32-37}$ target-vessel revascularization, ${ }^{20,32,35,37}$ stent thrombosis, ${ }^{20,33,37,40}$ stroke, ${ }^{34,37,38}$ and artythmia. ${ }^{20,33,36}$ Because some side effects occurred less frequently, we analyzed only the common adverse effects in this meta-analysis. No significant differences were found in the rates of AEs between stem cell treatment and control groups (Table 2 and Figure S2).

\section{Discussion}

Each year, 17 million people die from cardiovascular diseases worldwide, more than half of which are due to AMI. ${ }^{1,3,45}$ Traditional revascularization and drug treatment are used currently to prevent the deterioration of cardiac function that emerged after AMI, while the effects were limited. Hence, how to make the damaged myocardium cell regeneration becomes the urgent problem to be 


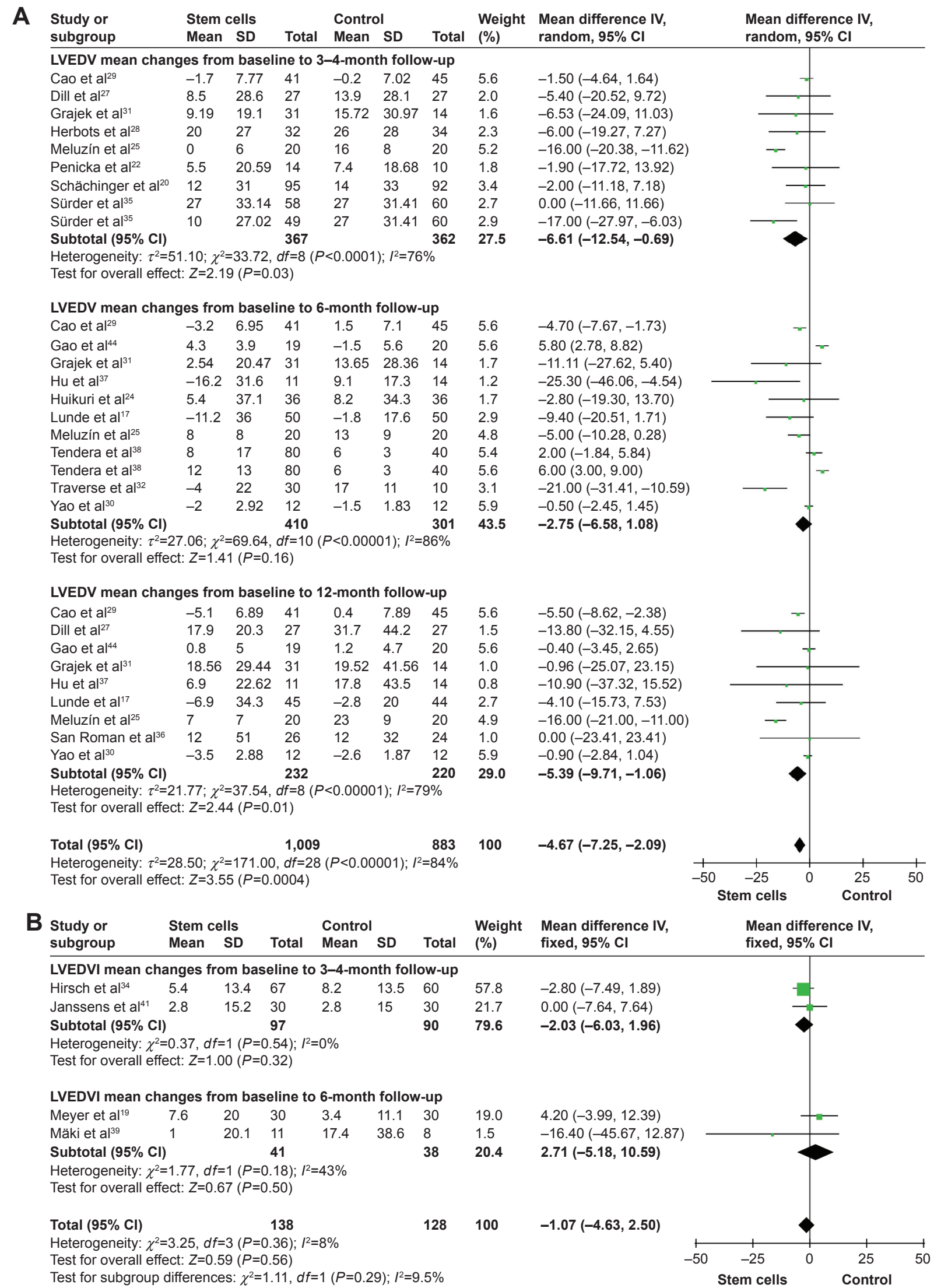

Figure 4 Forest plots of WMD with $95 \% \mathrm{Cl}$ in patients undergoing with stem cell therapy and controls in LVEDV (A) and LVEDVI (B).

Note: Random- and fixed-effect models were used.

Abbreviations: WMD, weighted mean difference; Cl, confidence interval; IV, inverse variance; LVEDV, left ventricular end-diastolic volume; LVEDVI, left ventricular enddiastolic volume index. 


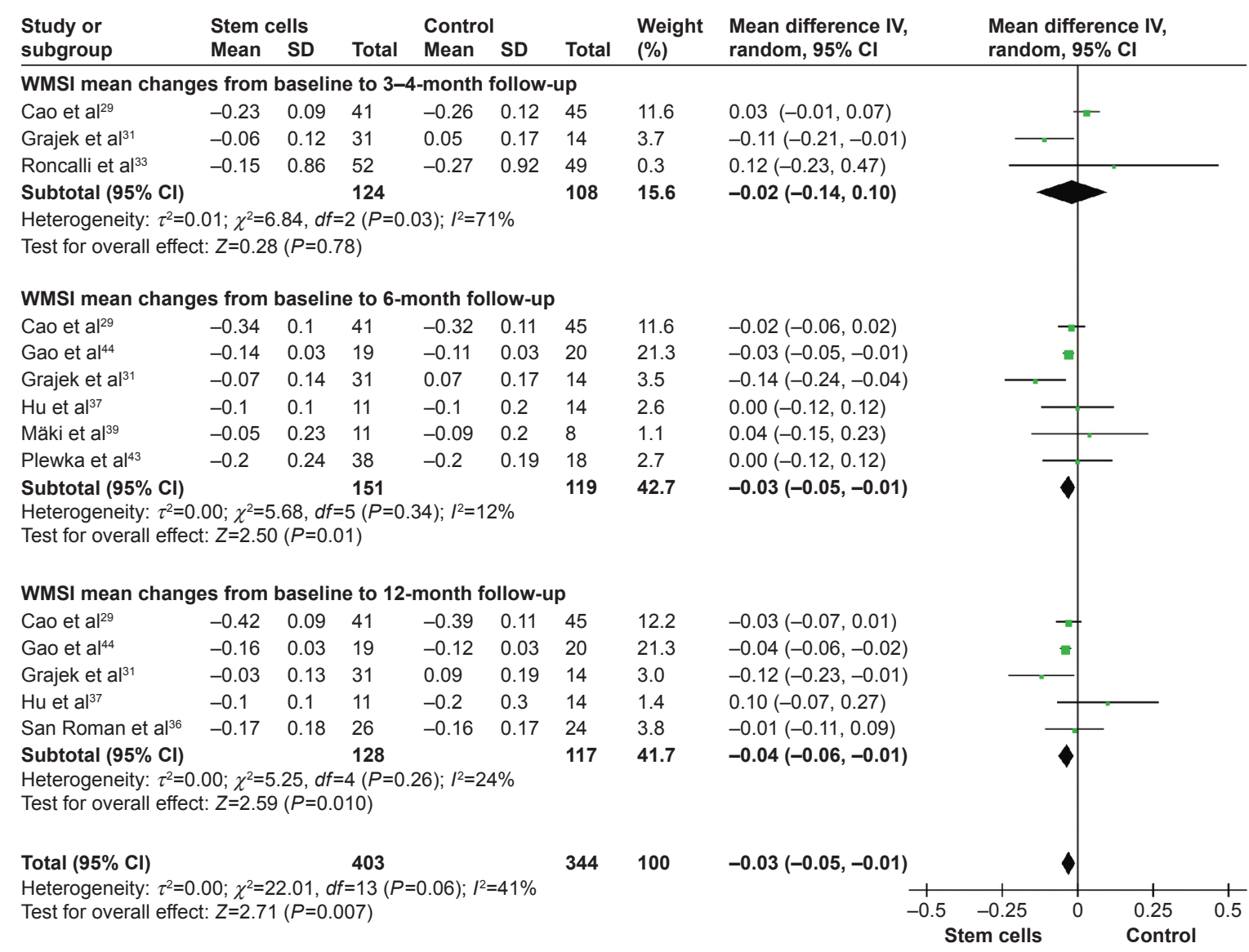

Figure 5 Effect of stem cell treatment on WMSI.

Note: Random-effect models were used.

Abbreviations: $\mathrm{Cl}$, confidence interval; IV, inverse variance; WMSI, wall mean score index.

solved recently. Stem cell-based therapies seem to be one of the most promising solutions. If the transplanted stem cells could successfully differentiate into myocardial cells and had the contractility of cardiac muscle fibers, which then could improve the heart function for AMI patients. ${ }^{45-47}$ Transplanted stem cells secrete various cytokines, growth factors and vascular endothelial growth factors, thereby promoting the proliferation of cells and the regeneration of vascular. ${ }^{48,49}$ In addition, the expression of heat shock protein 32 and heat shock protein 70 is also increased by the transplanted stem cells, which could promote the recovery of cardiac muscle cell function..$^{50}$ Our systemic review assessed the efficacy and safety of the stem cell treatment application in STEMI patients in multicountry based on the analysis of LVEF, LVESV, LVESVI, LVEDV, LVEDVI, WMSI, IS, and AEs. In this study, data indicate the significant improvement in LVEF, LVESV, LVEDV, WMSI, and IS after stem cell treatment, whereas there was no significant improvement in LVESVI and LVEDVI after stem cell transplantation compared with the controls.
Several important findings were revealed in this metaanalysis. We first demonstrated that stem cell therapy could significantly increase the 12-month LVEF (based SPECT); the 3-month to 4-month, 6-month, and 12-month LVEF (based echo); and the 3-month to 4-month LVEF (based MRI) in STEMI patients compared with the control group $(P<0.01$; Figure 2). No significant increase was found in 6-month LVEF (based MRI; $P=0.97$ ). Only the positive trend was proved to be existed. Currently, the use of MRI to detect LVEF is considered as the gold standard. ${ }^{51,52} \mathrm{In}$ this analysis, $46.4 \%$ of all trials use echo, while only $17.9 \%$ of all trials use MRI. Our logistic regression results showed that stem cell therapy could significantly increase long-term (12 months) LVEF ( $>3.15 \%)$ in STEMI patients. The effects of stem cell therapy on short-term (3 months to 4 months and 6 months) LVEF still need to be incorporated into larger number of patients.

Second, the 3-month to 4-month, 6-month, and 12-month LVESV showed favorable results in the stem cell therapy group compared with the control group ( $P \leq 0.05$, Figure 3 ). 


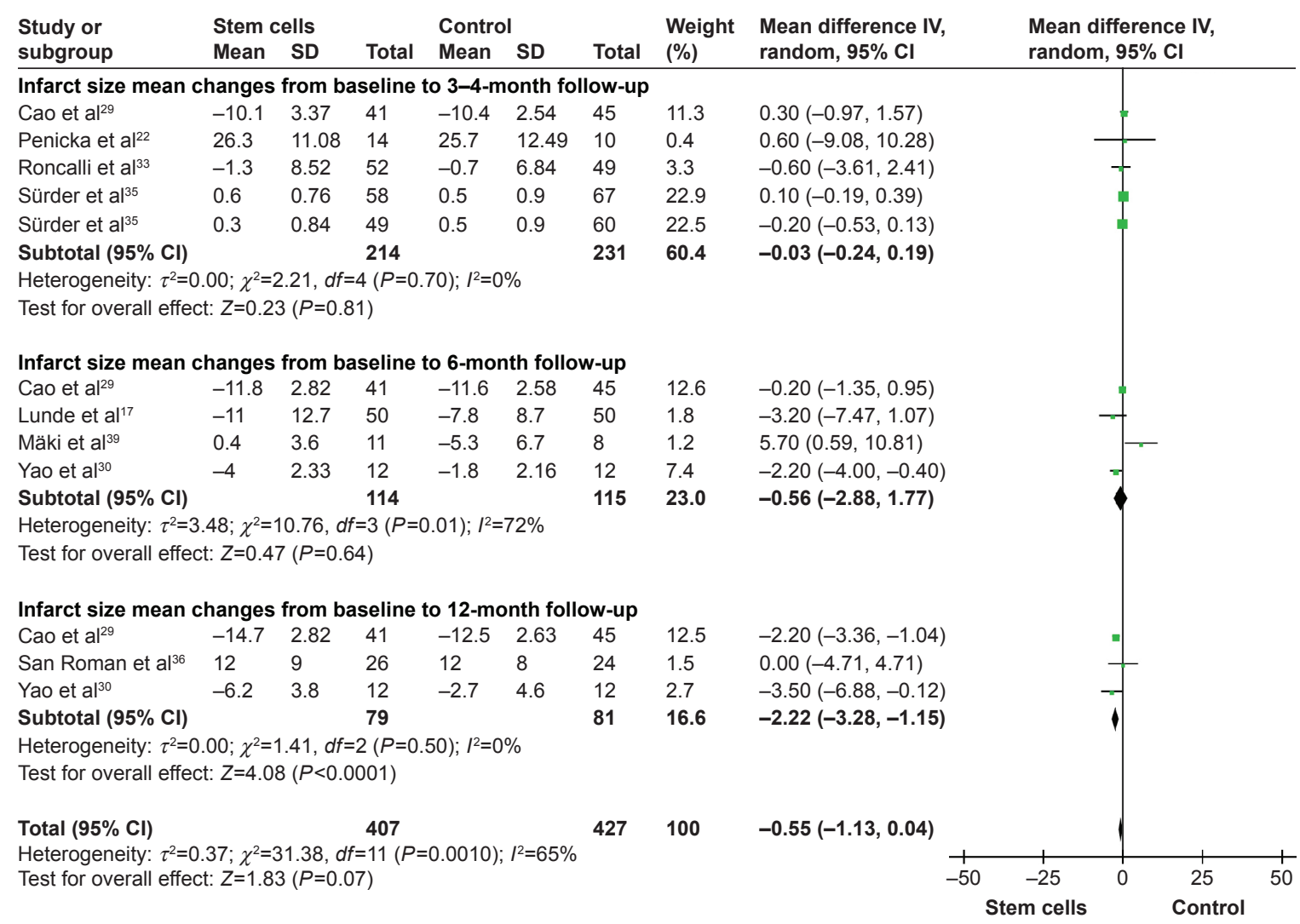

Figure 6 Effect of stem cell treatment on IS.

Note: Random-effect models were used.

Abbreviations: $\mathrm{Cl}$, confidence interval; IV, inverse variance; IS, infarct size.

Table 2 Pooled adverse outcome data

\begin{tabular}{|c|c|c|c|c|c|c|}
\hline Outcome & $\begin{array}{l}\text { Studies } \\
\text { reporting }\end{array}$ & $\begin{array}{l}\text { Events stem } \\
\text { cell treatment }\end{array}$ & $\begin{array}{l}\text { Events } \\
\text { control }\end{array}$ & Odds ratio & $95 \% \mathrm{Cl}$ & $P$-value \\
\hline \multicolumn{7}{|l|}{ Death } \\
\hline 3-6 months & 9 & $9 / 556$ & $6 / 455$ & 1.25 & $0.49-3.14$ & 0.64 \\
\hline $12-18$ months & 3 & $2 / 142$ & $7 / 148$ & 0.33 & $0.08-1.40$ & 0.13 \\
\hline \multicolumn{7}{|l|}{ Cardiac death } \\
\hline 3-6 months & 2 & $4 / 102$ & $3 / 99$ & 1.30 & $0.28-5.95$ & 0.74 \\
\hline \multicolumn{7}{|l|}{ Reinfarction } \\
\hline 3-6 months & 9 & $11 / 595$ & $|5 / 49|$ & 0.61 & $0.30-1.25$ & 0.17 \\
\hline $12-18$ months & 2 & $2 /|3|$ & $5 / 134$ & 0.68 & $0.01-39.75$ & 0.85 \\
\hline \multicolumn{7}{|l|}{ HF hospitalization } \\
\hline 3-6 months & 7 & $6 / 396$ & $9 / 375$ & 0.69 & $0.27-1.79$ & 0.45 \\
\hline $12-18$ months & 3 & $6 / 142$ & $6 / 148$ & 1.15 & $0.14-9.29$ & 0.90 \\
\hline \multicolumn{7}{|c|}{ Target-vessel revascularization } \\
\hline 3-6 months & 5 & $20 / 275$ & $27 / 261$ & 0.69 & $0.38-1.28$ & 0.24 \\
\hline $12-18$ months & 2 & $16 / 112$ & $24 / 117$ & 0.62 & $0.31-1.25$ & 0.18 \\
\hline \multicolumn{7}{|l|}{ Stent thrombosis } \\
\hline 3-6 months & 4 & $5 / 2 \mid 4$ & $5 / 216$ & 0.98 & $0.29-3.26$ & 0.97 \\
\hline $12-18$ months & 2 & $1 / 112$ & $3 / 117$ & 0.33 & $0.03-3.26$ & 0.34 \\
\hline \multicolumn{7}{|l|}{ Stroke } \\
\hline 3-6 months & 4 & $0 / 240$ & $0 / 159$ & - & - & - \\
\hline \multicolumn{7}{|l|}{ Arrhythmia } \\
\hline 3-6 months & 2 & $6 / 153$ & $6 / 152$ & 0.99 & $0.31-3.15$ & 0.99 \\
\hline $12-18$ months & 2 & $|1 /| 3 \mid$ & $11 / 134$ & 1.03 & $0.42-2.53$ & 0.95 \\
\hline
\end{tabular}

Abbreviations: $\mathrm{Cl}$, confidence interval; $\mathrm{HF}$, rehospitalization for heart failure. 
LVEDV also significantly decreased at 3-month to 4-month and 12-month follow-up compared with the controls $(P \leq 0.05$, Figure 4). LVESV and LVEDV are two surrogate markers for left ventricular adverse remodeling. No significant increase was found in LVESVI and LVEDVI $(P>0.05)$, and only the positive trend was proved to be existed. Mechanistically, ventricular enlargement is mainly due to the suddenly increased loading conditions after AMI, which leads to a series of reparative changes including the expansion of ventricle after programmed cell death, the formation of discrete collagen scars, and the myocardial hypertrophy in noninfarct area. ${ }^{29}$ Therefore, logistic regression helps us to conclude that stem cell treatment significantly limits LVESV increase and averts progressive LVEDV expansion in STEMI patients.

Furthermore, as one of the secondary end points, our analysis showed significant reduction in 6-month WMSI and 12-month WMSI in STEMI patients treated with stem cells compared with controls. WMSI serves as a well-characteristic indicator for the local systolic function of the heart. Tao et al reported that MSC could significantly decrease the WMSI in animals 10 weeks after AMI. ${ }^{33}$ Santoso et al ${ }^{54}$ also reported that the 3-month WMSI was decreased significantly from 1.57 at baseline to 1.37 after peripheral blood stem cell treatment. Stem cell therapy did not significantly decrease 3-month to 4-month WMSI in our meta-analysis $(P>0.05)$. This result might be due to the sparse number of patients counted in this study. Thereby, we have concluded based on logistic regression that stem cell therapy has a significant effect on WMSI (both long term and short term) in patients with STEMI.

In addition, our analysis showed a significant change in 12-month IS, which decreased in STEMI patients with the treatment of stem cells compared with controls. Changes in IS are commonly used to quantify the left ventricular function. Recently, research by Chen et al $^{55}$ on EPCs transplantation in AMI reported that after AMI, the expression of endothelial nitric oxide synthases was beneficial to deterioration prevention, infarcted size reduction, and the improvement in heart function by promoting the formation of blood vessels. In another trial, the decrease of IS in repeated BM-MNCs administration group was more significant than in single BM-MNCs administration control group. This finding suggests that the number and frequency of cell transplantation may play a key role in therapeutic efficacy to AMI patients. ${ }^{30}$ In the trial of Cao et al, ${ }^{29}$ the BM-MNC therapy did not further improve the myocardial viability of the infarcted area as assessed by SPECT 4 years after transplantation. Thus, the effects of stem cell therapy on IS still need to be incorporated into larger number of patients and longer follow-up.

Although great results were received in both AMI animal models and clinical studies using stem cell transplantation treatment, there are still some problems that need to be explored and settled in the future. First, what kinds of cell types are suitable for cell transplantation? At present, bone marrow-derived stem cell usage, which took up to $80 \%$ of the total stem cell therapy trials for AMI patients. Bone marrowderived stem cell is a group of hybrid cells, mainly including BM-MNCs, HSCs, BMSCs, etc. BM-MNCs have their own advantages, such as large reserves and simple separation process; however, the inflammatory reaction aggravation of myocardium by mixing a large number of white blood cells limits its performance. We believe that the higher purity of stem cells, the better treatment effect will be achieved. ${ }^{56,57}$ Second, the "NICH" that guarantee stem cells differentiate into cardiomyocytes? Microenvironment (named "NICH") is believed to affect stem cell differentiation, but the regulation mechanism of stem cell differentiation into cardiomyocytes remains unclear. Furthermore, the best timing for stem cell transplantation is also a critical point to be taken into account. The period of heart inflammation peaks 1-3 days after AMI, which might reduce the survival of the transplanted stem cells. The vessel wall in the infarct area forms $\sim 20$ days later after AMI, preventing the migration of transplanted stem cells. The secretion of growth factors such as vascular endothelial growth factor reaches its highest level on the seventh day after AMI. Hence, the best time point for stem cell transplantation is $\sim 1$ week after AMI. ${ }^{17,25-27,33}$

In summary, our meta-analysis demonstrates that stem cell therapy post-STEMI results in significant improvements in LVEF, LVESV, LVEDV, WMSI, and IS for STEMI patients with low rates of side effects.

\section{Limitations}

Although this meta-analysis showed that stem cells therapy is effective for STEMI patients, it also has certain contraindications. The 28 clinical trials in this systemic review were conducted in 13 countries, and not all trials were multicenter clinical research, so the results could not be extended to all STEMI patients around the world. Other factors might affect the outcome of this analysis, such as the total sample size, the follow-up time, and the process of stem cells transplantation. Second, some good efficacy clinical trials were excluded because they were not RCTs or for other reasons. So the effectiveness of the stem cells therapy might be underestimated. In addition, it should be 
stressed the conclusions of this meta-analysis are confirmed only to BM-MNCs, HSCs, EPCs, and BMSCs transfer after STEMI. The effectiveness of other stem cell types remains to be studied. Thus, future better design randomized multicenter clinical trials are required to develop and maximize the clinical potential of stem cell therapy.

\section{Future perspectives}

In the near future, stem cell therapy could potentially offer substantial benefits for STEMI patients. But before that, there are still many issues regarding the methodology of transplanting cells, treatment mechanism, and safety, which need to be solved. First, we need to definitively address the precise molecules and pathways, including microenvironment improvement and cell homing. Furthermore, we still need to identify the best cell types, explore the best cell culture condition and number, choose the best cell infusion method, and select the most appropriate outcome measures for stem cell therapy. In addition, we also need to select the ideal target patients. At last, with the continuous progress that is being made in biotechnology, the future stem cell therapy for heart disease patients will move toward individualized treatment.

\section{Conclusion}

Taken together, the results suggest that stem cell therapy has great potential as an efficacious clinical therapy for the treatment of STEMI patients after percutaneous coronary intervention. The results of these clinical trials are very promising and additional studies have to be performed with a more rigorous, larger sample size validation before stem cell therapy could be used in clinical practice.

\section{Acknowledgments}

The authors gratefully acknowledge the authors of the original clinical trials. Rong Li and Xiao-Ming Li are co-first authors of this work.

\section{Disclosure}

The authors report no conflicts of interest in this work.

\section{References}

1. Carville SF, Henderson R, Gray H. The acute management of STsegment-elevation myocardial infarction. Clin Med (Lond). 2015; 15(4):362-367.

2. Yee J, Rajpurohit N, Khan MA, Stys A. Review of acute coronary syndromes: diagnosis and management of ST-elevation myocardial infarction. S D Med. 2015;68(8):357-361.

3. Guimarães PO, Tricoci P. Ticagrelor, prasugrel, or clopidogrel in ST-segment elevation myocardial infarction: which one to choose? Expert Opin Pharmacother. 2015;16(13):1983-1995.
4. Afzal MR, Samanta A, Shah ZI, et al. Adult bone marrow cell therapy for ischemic heart disease: evidence and insights from randomized controlled trials. Circ Res. 2015;117(6):558-575.

5. Menendez ME, Memtsoudis SG, Opperer M, Boettner F, Gonzalez Della Valle A. A nationwide analysis of risk factors for in-hospital myocardial infarction after total joint arthroplasty. Int Orthop. 2015;39(4): 777-786.

6. Moran AE, Tzong KY, Forouzanfar MH, et al. Variations in ischemic heart disease burden by age, country, and income: the Global Burden of Diseases, Injuries, and Risk Factors 2010 study. Glob Heart. 2014;9(1): 91-99.

7. Moran AE, Forouzanfar MH, Roth GA, et al. The global burden of ischemic heart disease in 1990 and 2010: the Global Burden of Disease 2010 study. Circulation. 2014;129(14):1493-1501.

8. Lavall MC, Bagatini MD, Thomé GR, et al. Extracellular hydrolysis of adenine nucleotides and nucleoside adenosine is higher in patients with ST elevation than Non-ST elevation in acute myocardial infarction. Clin Lab. 2015;61(7):761-767.

9. Kook HY, Jeong MH, Oh S, et al. Current trend of acute myocardial infarction in Korea (from the Korea Acute Myocardial Infarction Registry from 2006 to 2013). Am J Cardiol. 2014;114(12):1817-1822.

10. Gnavi R, Rusciani R, Dalmasso M, et al. Gender, socioeconomic position, revascularization procedures and mortality in patients presenting with STEMI and NSTEMI in the era of primary PCI. Differences or inequities? Int $J$ Cardiol. 2014;176(3):724-730.

11. Sun D, Narsinh K, Wang H, et al. Effect of autologous bone marrow mononuclear cells transplantation in diabetic patients with ST-segment elevation myocardial infarction. Int J Cardiol. 2013;167(2):537-547.

12. Yu CW, Choi SC, Hong SJ, et al. Cardiovascular event rates in patients with ST-elevation myocardial infarction were lower with early increases in mobilization of Oct4(high)Nanog(high) stem cells into the peripheral circulation during a 4-year follow-up. Int J Cardiol. 2013; 168(3):2533-2539.

13. Porto I, De Maria GL, Leone AM, et al. Endothelial progenitor cells, microvascular obstruction, and left ventricular remodeling in patients with ST elevation myocardial infarction undergoing primary percutaneous coronary intervention. Am J Cardiol. 2013;112(6):782-791.

14. Miettinen JA, Salonen RJ, Ylitalo K, et al. The effect of bone marrow microenvironment on the functional properties of the therapeutic bone marrow-derived cells in patients with acute myocardial infarction. J Transl Med. 2012;10:66.

15. Zimmet H, Porapakkham P, Porapakkham P, et al. Short- and longterm outcomes of intracoronary and endogenously mobilized bone marrow stem cells in the treatment of ST-segment elevation myocardial infarction: a meta-analysis of randomized control trials. Eur J Heart Fail. 2012;14(1):91-105.

16. https://www.clinicaltrials.gov [homepage on the Internet]. ClinicalTrials. gov. Available from: https://www.clinicaltrials.gov/. Accessed June 21, 2016.

17. Lunde K, Solheim S, Aakhus S, et al. Intracoronary injection of mononuclear bone marrow cells in acute myocardial infarction. $N$ Engl $J$ Med. 2006;355(12):1199-1209.

18. Ge J, Li Y, Qian J, et al. Efficacy of emergent transcatheter transplantation of stem cells for treatment of acute myocardial infarction (TCTSTAMI). Heart. 2006;92(12):1764-1767.

19. Meyer GP, Wollert KC, Lotz J, et al. Intracoronary bone marrow cell transfer after myocardial infarction: 5-year follow-up from the randomized-controlled BOOST trial. Eur Heart J. 2009;30(24): 2978-2984.

20. Schächinger V, Erbs S, Elsässer A, et al. Intracoronary bone marrowderived progenitor cells in acute myocardial infarction. $N$ Engl $J$ Med. 2006;355(12):1210-1221.

21. Guo SZ [webpage on the Internet]. Assessing therapeutic efficacy of autologous mononuclear bone marrow cells transplantation with RT-MCE in AMI patients, Thesis, The University of Fudan, 2006. Available: http://epub.cnki.net/kns/brief/result.aspx?dbprefix $=\mathrm{scdb} \&$ action=scdbsearch\&db_opt=SCDB. Accessed May 25, 2016. 
22. Penicka M, Horak J, Kobylka P, et al. Intracoronary injection of autologous bone marrow-derived mononuclear cells in patients with large anterior acute myocardial infarction: a prematurely terminated randomized study. J Am Coll Cardiol. 2007;49(24):2373-2374.

23. Huang RC, Yao K, Qian JY, et al. Evaluation of myocardial viability with 201T1/18F-FDG DISA-SPECT technique in patients with acute myocardial infarction after emergent intracoronary autologous bone marrow mononuclear cells transplantation. Zhong hua Xin Xue Guan Bing Za Zhi. 2007;35(6):500-503.

24. Huikuri HV, Kervinen K, Niemelä M, et al. Effects of intracoronary injection of mononuclear bone marrow cells on left ventricular function, arrhythmia risk profile, and restenosis after thrombolytic therapy of acute myocardial infarction. Eur Heart J. 2008;29(22): 2723-2732.

25. Meluzín J, Janousek S, Mayer J, et al. Three-, 6-, and 12-month results of autologous transplantation of mononuclear bone marrow cells in patients with acute myocardial infarction. Int J Cardiol. 2008; 128(2):185-192.

26. Silva SA, Sousa AL, Haddad AF, et al. Autologous bone-marrow mononuclear cell transplantation after acute myocardial infarction: comparison of two delivery techniques. Cell Transplant. 2009;18(3): 343-352.

27. Dill T, Schächinger V, Rolf A, et al. Intracoronary administration of bone marrow-derived progenitor cells improves left ventricular function in patients at risk for adverse remodeling after acute ST-segment elevation myocardial infarction: results of the Reinfusion of Enriched Progenitor cells And Infarct Remodeling in Acute Myocardial Infarction study (REPAIR-AMI) cardiac magnetic resonance imaging substudy. Am Heart J. 2009;157(3):541-547.

28. Herbots L, D'hooge J, Eroglu E, et al. Improved regional function after autologous bone marrow-derived stem cell transfer in patients with acute myocardial infarction: a randomized, double-blind strain rate imaging study. Eur Heart J. 2009;30(6):662-670.

29. Cao F, Sun D, Li C, et al. Long-term myocardial functional improvement after autologous bone marrow mononuclear cells transplantation in patients with ST-segment elevation myocardial infarction: 4 years follow-up. Eur Heart J. 2009;30(16):1986-1994.

30. Yao K, Huang R, Sun A, et al. Repeated autologous bone marrow mononuclear cell therapy in patients with large myocardial infarction. Eur J Heart Fail. 2009;11(7):691-698.

31. Grajek S, Popiel M, Gil L, et al. Influence of bone marrow stem cells on left ventricle perfusion and ejection fraction in patients with acute myocardial infarction of anterior wall: randomized clinical trial: impact of bone marrow stem cell intracoronary infusion on improvement of microcirculation. Eur Heart J. 2010;31(6):691-702.

32. Traverse JH, McKenna DH, Harvey K, et al. Results of a phase I, randomized, double-blind, placebo-controlled trial of bone marrow mononuclear stem cell administration in patients following ST-elevation myocardial infarction. Am Heart J. 2010;160(3):428-434.

33. Roncalli J, Mouquet F, Piot C, et al. Intracoronary autologous mononucleated bone marrow cell infusion for acute myocardial infarction: results of the randomized multicenter BONAMI trial. Eur Heart J. 2011; 32(14):1748-1757.

34. Hirsch A, Nijveldt R, van der Vleuten PA, et al. Intracoronary infusion of mononuclear cells from bone marrow or peripheral blood compared with standard therapy in patients after acute myocardial infarction treated by primary percutaneous coronary intervention: results of the randomized controlled HEBE trial. Eur Heart J. 2011;32(14):1736-1747.

35. Sürder D, Manka R, Lo Cicero V, et al. Intracoronary injection of bone marrow-derived mononuclear cells early or late after acute myocardial infarction: effects on global left ventricular function. Circulation. 2013;127(19):1968-1979.

36. San Roman JA, Sánchez PL, Villa A, et al. Comparison of different bone marrow-derived stem cell approaches in reperfused STEMI. A Multicenter, Prospective, Randomized, Open-Labeled TECAM Trial. J Am Coll Cardiol. 2015;65(22):2372-2382.
37. Hu X, Huang X, Yang Q, et al. Safety and efficacy of intracoronary hypoxia-preconditioned bone marrow mononuclear cell administration for acute myocardial infarction patients: the CHINA-AMI randomized controlled trial. Int J Cardiol. 2015;184:446-451.

38. Tendera M, Wojakowski W, Ruzyłło W, et al. Intracoronary infusion of bone marrow-derived selected CD34+CXCR4+ cells and non-selected mononuclear cells in patients with acute STEMI and reduced left ventricular ejection fraction: results of randomized, multicentre Myocardial Regeneration by Intracoronary Infusion of Selected Population of Stem Cells in Acute Myocardial Infarction (REGENT) Trial. Eur Heart J. 2009;30(11):1313-1321.

39. Mäki MT, Koskenvuo JW, Ukkonen H, et al. Cardiac function, perfusion, metabolism, and innervation following autologous stem cell therapy for acute ST-elevation myocardial infarction. A FINCELLINSIGHT sub-study with PET and MRI. Front Physiol. 2012;3:6.

40. Bystroň M, Cervinka $\mathrm{P}$, Spaček R, et al. Randomized comparison of endothelial progenitor cells capture stent versus cobalt-chromium stent for treatment of ST-elevation myocardial infarction. Six-month clinical, angiographic, and IVUS follow-up. Catheter Cardiovasc Interv. 2010;76(5):627-631.

41. Janssens S, Dubois C, Bogaert J, et al. Autologous bone marrowderived stem-cell transfer in patients with ST-segment elevation myocardial infarction: double-blind, randomised controlled trial. Lancet. 2006;367(9505):113-121.

42. Xue $Z$ [webpage on the Internet]. The clinical research on treatment for Acute Myocardial infarction with autologous bone marrow stem cell, Thesis, The University of Hebei medical, 2007. Available: http:// epub.cnki.net/kns/brief/result.aspx?dbprefix=scdb\&action=scdbsearch \&db_opt=SCDB. Accessed May 25, 2016.

43. Plewka M, Krzemińska-Pakuła M, Lipiec P, et al. Effect of intracoronary injection of mononuclear bone marrow stem cells on left ventricular function in patients with acute myocardial infarction. Am J Cardiol. 2009; 104(10):1336-1342.

44. Gao LR, Pei XT, Ding QA, et al. A critical challenge: dosage-related efficacy and acute complication intracoronary injection of autologous bone marrow mesenchymal stem cells in acute myocardial infarction. Int J Cardiol. 2013;168(4):3191-3199.

45. Santhakumar R, Vidyasekar P, Verma RS. Cardiogel: a nano-matrix scaffold with potential application in cardiac regeneration using mesenchymal stem cells. PLoS One. 2014;9(12):e114697.

46. Makino S, Fukuda K, Miyoshi S, et al. Cardiomyocytes can be generated from marrow stromal cells in vitro. J Clin Invest. 1999;103(5):697-705.

47. Wei H, Tan G, Manasi. One-step derivation of cardiomyocytes and mesenchymal stem cells from human pluripotent stem cells. Stem Cell Res. 2012;9(2):87-100.

48. Suzuki E, Fujita D, Takahashi M, Oba S, Nishimatsu H. Adipose tissuederived stem cells as a therapeutic tool for cardiovascular disease. World $J$ Cardiol. 2015;7(8):454-465.

49. Wang Y, Zhang G, Hou Y, et al. Transplantation of microencapsulated Schwann cells and mesenchymal stem cells augment angiogenesis and improve heart function. Mol Cell Biochem. 2012;366(1-2): 139-147.

50. Zhang S, Guo J, Zhang P, et al. Transplantation of bone marrow cells up-regulated the expressions of HSP32 and HSP70 in the acute ischemic myocardium. Beijing Da Xue Xue Bao. 2003;35(5):476-480.

51. Springeling T, Uitterdijk A, Rossi A, et al. Evolution of reperfusion post-infarction ventricular remodeling: new MRI insights. Int J Cardiol. 2013;169(5):354-358.

52. Springeling T, Kirschbaum SW, Rossi A, et al. Late cardiac remodeling after primary percutaneous coronary intervention-five-year cardiac magnetic resonance imaging follow-up. Circ J. 2013;77(1):81-88.

53. Tao B, Cui M, Wang C, et al. Percutaneous intramyocardial delivery of mesenchymal stem cells induces superior improvement in regional left ventricular function compared with bone marrow mononuclear cells in porcine myocardial infarcted heart. Theranostics. 2015;5(2): 196-205. 
54. Santoso T, Irawan C, Alwi I, et al. Safety and feasibility of combined granulocyte colony stimulating factor and erythropoetin based-stem cell therapy using intracoronary infusion of peripheral blood stem cells in patients with recent anterior myocardial infarction: one-year follow-up of a phase 1 study. Acta Med Indones. 2011;43(2):112-121.

55. Chen X, Gu M, Zhao X, Zheng X, Qin Y, You X. Deterioration of cardiac function after acute myocardial infarction is prevented by transplantation of modified endothelial progenitor cells overexpressing endothelial NO synthases. Cell Physiol Biochem. 2013;31(2-3): $355-365$.
56. Sheu JJ, Lee FY, Yuen CM, et al. Combined therapy with shock wave and autologous bone marrow-derived mesenchymal stem cells alleviates left ventricular dysfunction and remodeling through inhibiting inflammatory stimuli, oxidative stress \& enhancing angiogenesis in a swine myocardial infarction model. Int J Cardiol. 2015;193:69-83.

57. Ter Horst EN, Naaijkens BA, Krijnen PA, Van Der Laan AM, Piek JJ, Niessen HW. Induction of a monocyte/macrophage phenotype switch by mesenchymal stem cells might contribute to improved infarct healing postacute myocardial infarction. Minerva Cardioangiol. 2013; 61(6):617-625. 


\section{Supplementary materials}

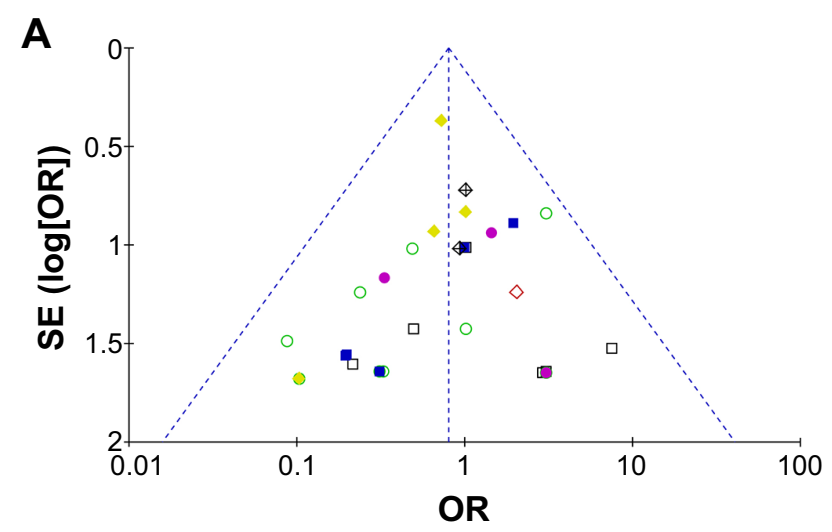

\begin{tabular}{|ll|}
\hline Subgroups & \\
$\square$ Death & $\diamond$ Target-vessel revascularization \\
$\diamond$ Cardiac death & - Stent thrombosis \\
$\odot$ Reinfarction & $\boxplus$ Stroke \\
- HF hospitalization & $\oplus$ Arrhythmia \\
\hline
\end{tabular}

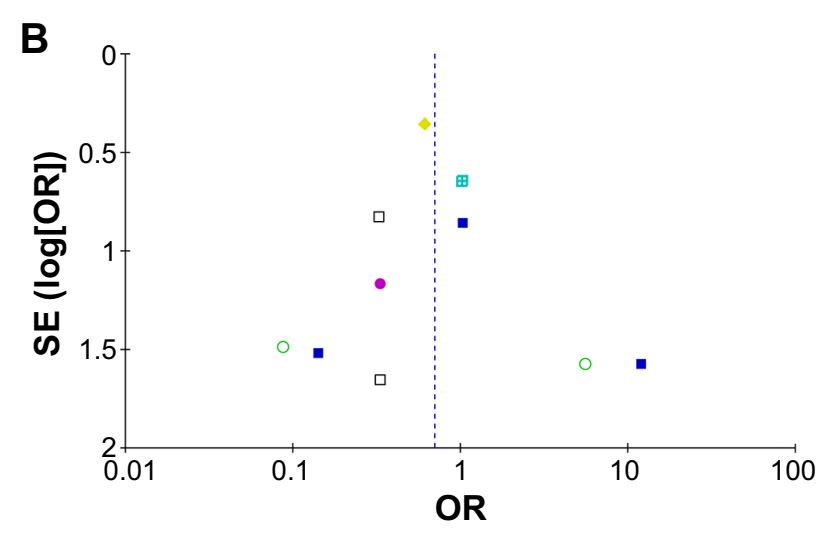

\begin{tabular}{|ll|}
\hline Subgroups & \\
$\square$ Death & Target-vessel revascularization \\
$\circ$ Reinfarction & - Stent thrombosis \\
$\square$ HF hospitalization & $\boxplus$ Arrhythmia
\end{tabular}

Figure SI A funnel plot of AEs generated by Review Manager Version 5.0.

Note: (A) 3-6 months, (B) 12-18 months.

Abbreviations: AE, adverse effect; SE, standard error; OR, odds ratio; HF, rehospitalization for heart failure. 


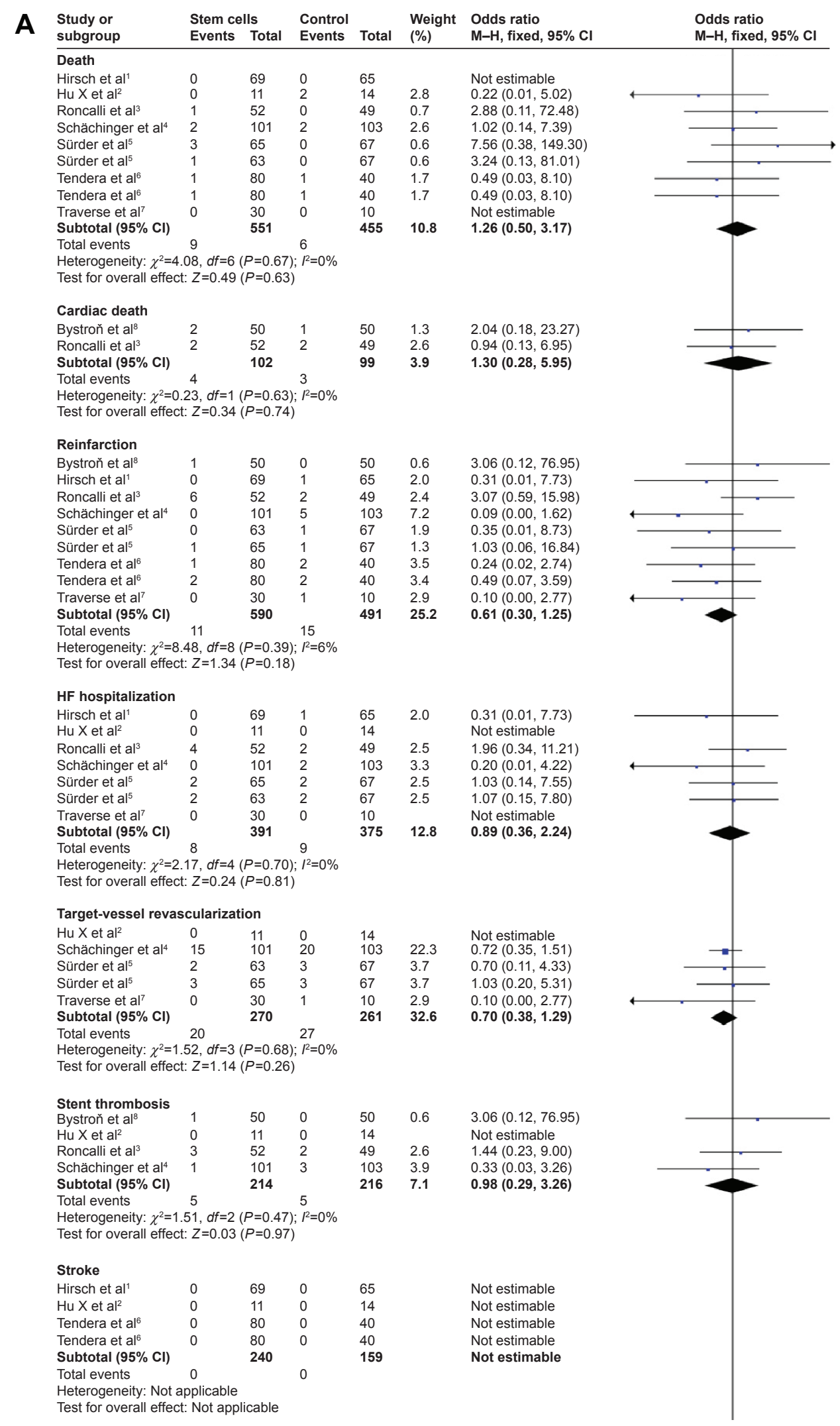

Figure S2 (Continued) 


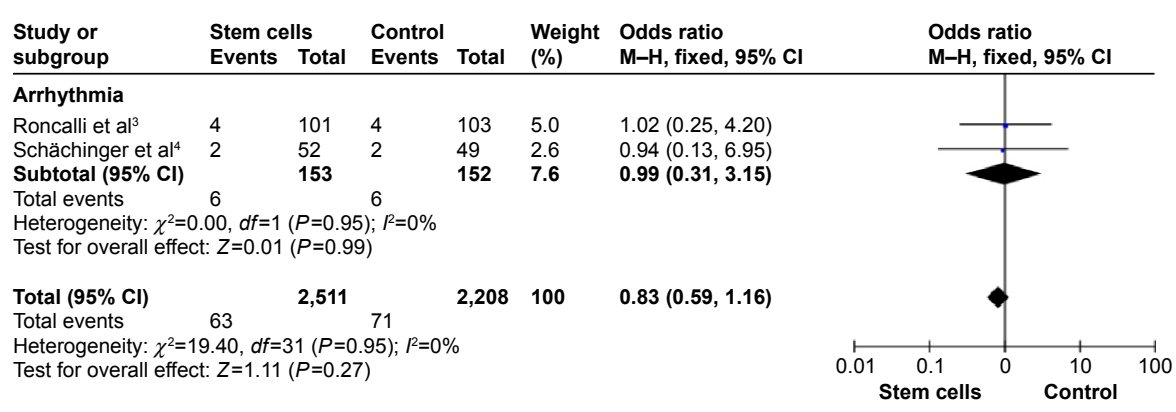

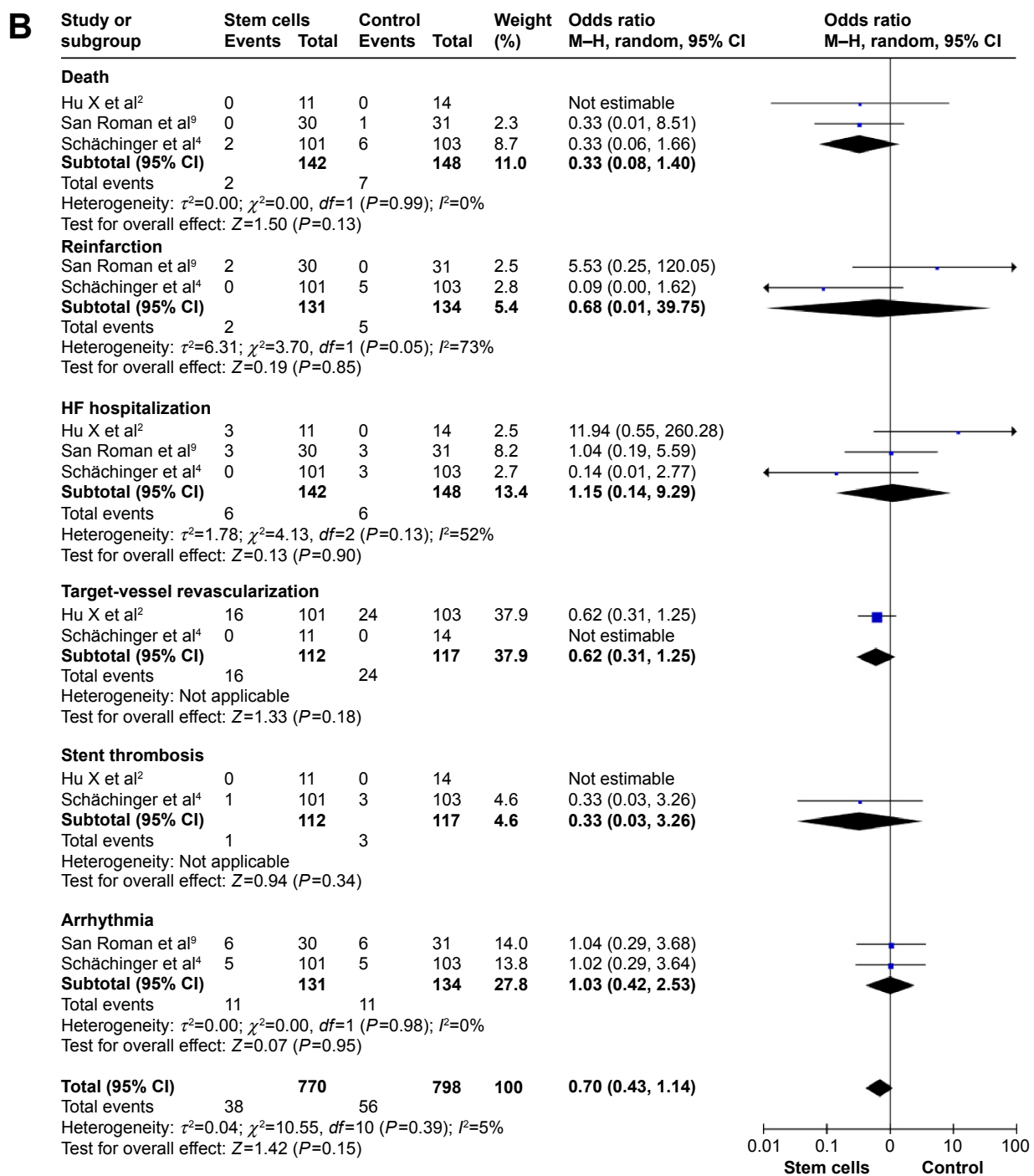

Figure S2 Effect of stem cell treatment on AEs.

Notes: Fixed-effect and random-effect models were used. (A) 3-6 months, (B) 12-18 months.

Abbreviations: $\mathrm{AE}$, adverse effect; $\mathrm{Cl}$, confidence interval; $\mathrm{HF}$, rehospitalization for heart failure; $\mathrm{M}-\mathrm{H}$, Mantel-Haenszel test. 


\section{References}

1. Hirsch A, Nijveldt R, van der Vleuten PA, et al. Intracoronary infusion of mononuclear cells from bone marrow or peripheral blood compared with standard therapy in patients after acute myocardial infarction treated by primary percutaneous coronary intervention: results of the randomized controlled HEBE trial. Eur Heart J. 2011;32(14): 1736-1747.

2. Hu X, Huang X, Yang Q, et al. Safety and efficacy of intracoronary hypoxia-preconditioned bone marrow mononuclear cell administration for acute myocardial infarction patients: The CHINA-AMI randomized controlled trial. Int J Cardiol. 2015;184:446-451.

3. Roncalli J, Mouquet F, Piot C, et al. Intracoronary autologous mononucleated bone marrow cell infusion for acute myocardial infarction: results of the randomized multicenter BONAMI trial. Eur Heart J. 2011;32(14):1748-1757.

4. Schächinger V, Erbs S, Elsässer A, et al. Intracoronary bone marrowderived progenitor cells in acute myocardial infarction. $N$ Engl J Med. 2006;355(12):1210-1221.

5. Sürder D, Manka R, Lo Cicero V, et al. Intracoronary injection of bone marrow-derived mononuclear cells early or late after acute myocardial infarction: effects on global left ventricular function. Circulation. 2013;127(19):1968-1979.
6. Tendera M, Wojakowski W, Ruzyłło W, et al. Intracoronary infusion of bone marrow-derived selected CD34+CXCR4+ cells and non-selected mononuclear cells in patients with acute STEMI and reduced left ventricular ejection fraction: results of randomized, multicentre Myocardial Regeneration by Intracoronary Infusion of Selected Population of Stem Cells in Acute Myocardial Infarction (REGENT) Trial. Eur Heart J. 2009;30(11):1313-1321.

7. Traverse JH, McKenna DH, Harvey K, et al. Results of a phase I, randomized, double-blind, placebo-controlled trial of bone marrow mononuclear stem cell administration in patients following ST-elevation myocardial infarction. Am Heart J. 2010;160(3):428-434.

8. Bystroň M, Cervinka $\mathrm{P}$, Spaček R, et al. Randomized comparison of endothelial progenitor cells capture stent versus cobalt-chromium stent for treatment of ST-elevation myocardial infarction. Six-month clinical, angiographic, and IVUS follow-up. Catheter Cardiovasc Interv. 2010;76(5):627-631.

9. San Roman JA, Sánchez PL, Villa A, et al. Comparison of different bone marrow-derived stem cell approaches in reperfused STEMI. A Multicenter, Prospective, Randomized, Open-Labeled TECAM Trial. J Am Coll Cardiol. 2015;65(22):2372-2382.
Therapeutics and Clinical Risk Management

\section{Publish your work in this journal}

Therapeutics and Clinical Risk Management is an international, peerreviewed journal of clinical therapeutics and risk management, focusing on concise rapid reporting of clinical studies in all therapeutic areas, outcomes, safety, and programs for the effective, safe, and sustained use of medicines. This journal is indexed on PubMed Central, CAS,

\section{Dovepress}

EMBase, Scopus and the Elsevier Bibliographic databases. The manuscript management system is completely online and includes a very quick and fair peer-review system, which is all easy to use. Visit http://www.dovepress.com/testimonials.php to read real quotes from published authors.

Submit your manuscript here: http://www.dovepress.com/therapeutics-and-clinical-risk-management-journal 